\title{
Effects of summer flooding on floodplain biogeochemistry in Poland; implications for increased flooding frequency
}

\author{
Artur M. Banach · Katarzyna Banach · Eric J. W. Visser • \\ Zofia Stępniewska · Antoine J. M. Smits · Jan G. M. Roelofs • \\ Leon P. M. Lamers
}

Received: 4 March 2008/Accepted: 23 January 2009/Published online: 17 February 2009

(C) The Author(s) 2009. This article is published with open access at Springerlink.com

\begin{abstract}
The frequency of summer flood events has strongly increased in Eastern Europe during the last decades. The creation of water storage areas to avoid flooding is often combined with the recreation of more natural and biodiverse riverine systems. This urges the need to understand the consequences of summer inundation, when microbial activity is significantly higher than during winter inundation, for floodplain biogeochemistry. In order to test the interacting effects of temporal
\end{abstract}

A. M. Banach · K. Banach · Z. Stępniewska

Department of Biochemistry and Environmental

Chemistry, The John Paul II Catholic University

of Lublin, Kraśnicka 102, 20-718 Lublin, Poland

\begin{abstract}
A. M. Banach - J. G. M. Roelofs - L. P. M. Lamers ( $ه)$
Department of Aquatic Ecology \& Environmental

Biology, Radboud University Nijmegen, Toernooiveld 1,

6525 ED Nijmegen, The Netherlands

e-mail: L.Lamers@science.ru.nl
\end{abstract}

K. Banach · E. J. W. Visser

Department of Experimental Plant Ecology,

Radboud University Nijmegen, Toernooiveld 1,

6525 ED Nijmegen, The Netherlands

\author{
A. J. M. Smits \\ Centre for Sustainable Management of Resources, \\ Radboud University Nijmegen, Toernooiveld 1, \\ 6525 ED Nijmegen, The Netherlands
}

flooding, water quality and agricultural use we used a mesocosm design with sods including vegetation from an area along a tributary of the Vistula River, where water storage compartments have been planned. Concentrations of nitrate and sulphate in the flood water, expected to interfere with soil redox processes, were varied at environmentally relevant concentrations. Inundation led to increased nutrient mobilization in all treatments, particularly for phosphate which reached very high concentrations in both soil water (200-300 $\left.\mu \mathrm{mol} \mathrm{l}^{-1}\right)$ and overlaying surface water $\left(25-35 \mu \mathrm{mol} 1^{-1}\right)$ as a result of iron reduction. The response was clearly linked to different soil characteristics like the Olsen $\mathrm{P}$ concentration, probably caused by varying kind of land use. Unexpectedly, the flood water quality played a less important role in the response to shortterm flooding. This could partly be explained by the relatively low infiltration rate into these waterlogged soils, indicating the importance of local hydrology. The findings of this study are important to understand and predict the effects of (more frequent) summer flooding of Eastern European rivers. It also indicates that it is necessary to take into account the soil quality in assessing the consequences of planned measures on biodiversity and ecosystem functioning.

Keywords Biodiversity - Eutrophication · Global climate change $\cdot$ Phosphate .

Redox potential $\cdot$ Wetland 


\section{Introduction}

Pristine floodplain areas along rivers are among the most biodiverse environments at a global scale. In addition, they offer several functions including flood control, mitigation of pollutants and nutrients, sediment accretion, control of erosion, groundwater recharge and water supply (Hartig et al. 1997, Tockner and Stanford 2002). However, river regulation, wastewater discharge and intensive agriculture have caused strong changes and nowadays floodplains are among the most altered landscapes worldwide and have become species-poor, over-fertilized, and polluted (Nienhuis et al. 2002; Tockner and Stanford 2002).

During the last decades there has been an increasing tendency of flood events in Europe that were mainly caused by heavy precipitation events, which is probably related to climate change (Bronstert 2003; Linnerooth-Bayer and Amendola 2003; Mitchell 2003; Ulbrich et al. 2003; Kundzewicz 2005). Especially in Eastern European countries, including Poland, frequencies of peak discharges and summer flooding have significantly increased, even though these rivers are much less regulated than in Western Europe. Severe and dangerous summer flood events occurred in 1997 (Odra and Vistula River), 2001 (Vistula River) and 2002 (Elbe) due to intensive precipitation (Kundzewicz 2005; Kundzewicz et al. 2005; EEA 2007).

Flooding events may cause significant economic damage and casualties in inhabited, industrial and agricultural areas of the floodplains. These disasters show the necessity of finding new solutions, because raising dikes and levies does not seem to support efficient protection anymore. New strategies have been proposed, such as the re-creation of more natural riverine systems, by allowing more space for the rivers (Smits et al. 2000; Van Stokkom et al. 2005). In this model the river can again reach its adjacent lands, the former regularly flooded wetlands that have been transformed into meadows and arable lands. In this way, these areas can be used for temporary storage of surplus water during peak discharge.

Wetlands may accumulate nutrients (e.g., via sedimentation, binding to soil particles and plant uptake) which can result in high biomass productivity and low biodiversity. However, they can also become significant sources of these substances, especially during flood peaks which may have severe consequences for river water quality (Lamers et al. 2006; Loeb et al. 2007). As a result of flooding, huge amounts of phosphate can be mobilized and potentially phytotoxic, reduced compounds such as sulphide, nitrite or ammonium may accumulate, strongly influencing vegetation development (Snowden and Wheeler 1993; Moore and Reddy 1994; Lucassen et al. 2000, 2002).

Phosphorus eutrophication resulting from flooding can be regulated by $\mathrm{P}$ saturation in the soil, interacting with floodwater chemistry. In floodplain soils containing high amounts of organic matter, sulphate is known to increase the mobilization of phosphate, as has been shown for fens including riverine marshes (Lamers et al. 2006; Loeb et al. 2007). In contrast, high nitrate concentrations in the surface water of polluted rivers may mitigate phosphate mobilization, as nitrate is a more favourable electron acceptor than iron or sulphate in microbial redox reactions (Lucassen et al. 2004; Lamers et al. 2006).

Water management in many countries including Poland is mainly based on dike protection. However, the recent events have proved that there is a strong need for floodwater storage basins in order to cope with the intensification of flooding risks, e.g., along the Vistula River (Kuźniar et al. 2002). This restoration strategy is often combined with the re-creation of biodiverse wetlands as a target. This appears, however, to be very difficult and often fails due to biogeochemical constraints related to water and soil quality, in addition to direct effects of flooding on the vegetation present (Lamers et al. 2006). The present paper will therefore focus on the consequences of summer inundation, when microbial conversion rates are higher than during winter flooding, on the biogeochemistry of floodplains in relation to land use (fertilization) and water quality (sulphate and nitrate), as these factors are hypothesized to be constraints. The presumably important interaction between water and soil quality has received little attention in other studies, and does not only generate information about the biogeochemical processes involved, but it also provides a feasibility assessment for the creation of water storage areas in general, and for the specific location along the tributary of the Vistula in Poland in particular.

To be able to study the effects of flood events under controlled conditions, we used a mesocosm approach with sods from two adjacent locations differing with respect to the kind of land use. We 
investigated if 1-month inundation leads to significant changes in nutrient availability, both in soil water and in surface water, and how this is related to surface water composition (sulphate, nitrate) and soil quality. The outcome of the experiment has important implications for the combination of wetland creation and increased floodwater storage in spring and summer, not only with respect to the biogeochemical key processes that may form constraints for nature management and water management, but also for the choice of suitable locations.

\section{Materials and methods}

Research area

For our study, we selected a former floodplain area (Kosiorów Village, $51^{\circ} 13^{\prime} \mathrm{N} ; 21^{\circ} 51^{\prime}$ E; Fig. 1) in Poland along Chodelka River, a tributary of the middle part of the Vistula River which showed an increased frequency of summer flooding during the last decade. This location has been proposed as a storage basin to take back-flowing water from the Vistula during peaks of discharge. We selected two neighbouring agricultural meadows located close to the river that show clear differences in fertilization history, which is expected to influence the biogeochemical response to flooding as suggested in the introduction (Table 1). Both locations are representative for this area and comprise of species-rich grasslands with Deschampsia cespitosa L. and Holcus lanatus L. as dominant plant species. The first meadow is cultivated for hay-making (haylandcoded HAY), fertilized with nitrogen, phosphorus and potassium at unknown dosage and mowed twice a year, in spring and summer. The second grassland is less fertilized, remains unmowed but is grazed (pasture-PAS) at a low density of 1 animal per ha. Both meadows show the same peaty soil type (upper $20 \mathrm{~cm}$ : $40-50 \%$ organic matter; with the inorganic fraction comprising $38-44 \%$ sand, $8-12 \%$ silt and $4 \%$ clay) with the water table $30 \mathrm{~cm}$ below the soil surface at average. The hayland soil contained less organic matter and the water content was lower (Table 1). The concentration of Olsen $\mathrm{P}$, as an estimate of plant available $\mathrm{P}$, was two times higher whilst the labile P-fraction was almost six times higher in the HAY soil. Olsen-extractable $\mathrm{P}$ was, however, high at both

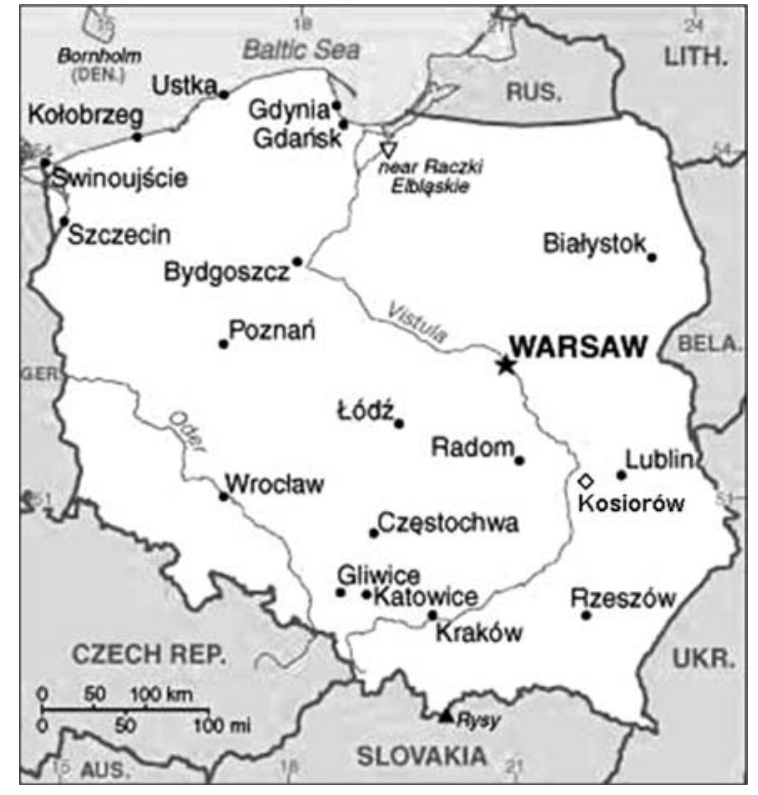

Fig. 1 Location of the sampling area (diamond) in Poland

Table 1 Soil characteristics for both tested soils; concentrations are given in $\mu \mathrm{mol} 1^{-1}$ of bulk soil

\begin{tabular}{|c|c|c|c|c|c|}
\hline Characteristics & Pasture & & Hayland & & Sign \\
\hline Water content & 50 & (2) & 37 & (2) & $* * *$ \\
\hline Organic matter & 54 & (1) & 41 & (3) & $* * *$ \\
\hline Bulk density & 0.28 & $(0.01)$ & 0.42 & $(0.02)$ & $* * *$ \\
\hline $\mathrm{pH}$ & 6.4 & $(0.2)$ & 6.2 & $(0.1)$ & NS \\
\hline Total S & 40,858 & $(1,776)$ & 52,321 & $(4,376)$ & $*$ \\
\hline $\mathrm{NO}_{3}^{-\mathrm{a}}$ & 2,236 & $(232)$ & 946 & (107) & $* * *$ \\
\hline $\mathrm{NH}_{4}^{+} \mathrm{b}$ & 180 & (24) & 279 & (76) & NS \\
\hline Olsen P & 1,863 & $(238)$ & 3,818 & $(435)$ & $* * *$ \\
\hline Total P & 8,833 & $(482)$ & 10,508 & $(886)$ & NS \\
\hline Amorphous Fe & 78,140 & $(3,393)$ & 76,671 & $(8,668)$ & NS \\
\hline Total Fe & 100,982 & $(5,094)$ & 117,560 & $(10,480)$ & NS \\
\hline Total Fe:P & 11.6 & $(0.4)$ & 11.0 & $(0.9)$ & NS \\
\hline (Fe minus $\mathrm{S}$ ): $\mathrm{P}$ & 6.9 & $(0.4)$ & 6.1 & $(0.6)$ & NS \\
\hline Labile $\mathrm{P}$ fraction & 16 & (1) & 90 & (10) & $* * *$ \\
\hline $\mathrm{Fe} / \mathrm{Al}$ bound $\mathrm{P}$ & 760 & (37) & 1,631 & (147) & $* * *$ \\
\hline $\mathrm{Ca}$ bound $\mathrm{P}$ & 2,981 & (119) & 3,178 & $(417)$ & NS \\
\hline Organic $\mathrm{P}$ & 5,077 & (383) & 5,609 & (484) & NS \\
\hline
\end{tabular}

Means are given, with their SEMs. Moisture and organic matter contents are expressed in \%, bulk density in $\mathrm{g}$ of dry soil per $\mathrm{ml}$ of fresh soil

a Water extractable nitrate

b $\mathrm{NaCl}$ extractable ammonium

$* p<0.05$; ** $p<0.01$; *** $p<0.001$; NS non-significant 
locations, suggesting that the pasture has also been fertilized in the past although this may also be partly the result of increased peat decomposition and $\mathrm{P}$ mineralization. Total concentration of $\mathrm{P}$ did not differ between both locations. Both soils were characterized by high iron concentrations (for both total and amorphic iron), but PAS showed much lower iron/ aluminium bound $\mathrm{P}(p<0.001)$. Nitrate concentrations were higher on this location, while total sulphur concentrations were lower (Table 1).

\section{Experimental design}

In total, forty sods $(30 \times 30 \times 12 \mathrm{~cm} ; 20$ per sublocation) with living vegetation were collected and transported in plastic containers to the laboratory in Nijmegen, The Netherlands. Each of the sods was fitted into a separate glass container $(25 \times 25 \times 30 \mathrm{~cm})$ placed in a climate controlled room at a constant flux of $100 \mu \mathrm{mol} \mathrm{m} \mathrm{m}^{-2} \mathrm{~s}^{-1}$ (PAR) with a 16-h day-light photoperiod (five $400 \mathrm{~W}$ high pressure metal-halide lamps HPI-T, Philips, Eindhoven, The Netherlands), an ambient air temperature of $17^{\circ} \mathrm{C}$ and a relative air humidity of $60 \%$.

The sods were divided into five experimental groups for both sub-locations $(n=4$ for each meadow, randomly distributed), of which four were flooded with different water qualities, and the fifth represented a non flooded control. We applied the following water treatments: flooded control (Cfl) based on the Chodelka River water quality, enriched with nitrate $(\mathrm{N})$, sulphate $(\mathrm{S})$ or the combination of $\mathrm{NO}_{3}$ and $\mathrm{SO}_{4}(\mathrm{SN})$ (Table 2).

The last treatment reflected conditions without flooding (moist control, $\mathrm{Cm}$ ). The $\mathrm{Cm}$ sods were watered weekly with artificial rainwater containing $5 \mathrm{mg}^{-1}$ of sea-salt, (Wiegandt GmbH, Krefeld, Germany) in order to keep the groundwater level at $10 \mathrm{~cm}$ below soil surface to avoid desiccation of the sods. Table 2 shows the different treatments, for which analytical grade purity chemicals (Fluka, Germany) and demineralized water were used. Each flooded sod received water from a separate stock by means of a flow-through system (peristaltic pumps Masterflex 7568-10, Cole-Parmer, Vernon Hills, IL, USA with black silicone tubes) at a flow speed of $60 \mathrm{ml} \mathrm{h}^{-1}\left(101\right.$ week $\left.^{-1}\right)$. The level of the floodwater above the soil was $20 \mathrm{~cm}$, resembling shallow flooding. The mesocosm experiment was conducted
Table 2 Chemical composition (concentrations in $\mu \mathrm{mol} 1^{-1}$ ) of artificial flood-water for each treatment

\begin{tabular}{lrrrr}
\hline Salt & \multicolumn{1}{l}{$\mathrm{SN}$} & \multicolumn{1}{l}{$\mathrm{N}$} & $\mathrm{Cfl}$ \\
\hline $\mathrm{CaCl}_{2} \cdot 2 \mathrm{H}_{2} \mathrm{O}$ & 610 & 610 & 610 & 610 \\
$\mathrm{KCl}$ & 240 & 240 & 240 & 240 \\
$\mathrm{MgCl}_{2} \cdot 6 \mathrm{H}_{2} \mathrm{O}$ & 75 & 75 & 75 & 75 \\
$\mathrm{Na}_{2} \mathrm{SO}_{4}$ & 1,000 & 1,000 & 100 & 100 \\
$\mathrm{NaNO}_{3}$ & 1,000 & 25 & 1,000 & 25 \\
$\mathrm{NaHCO}_{3}$ & 2,000 & 2,000 & 2,000 & 2,000 \\
$\mathrm{NaCl}$ & 0 & 975 & 1,800 & 2,775 \\
\hline
\end{tabular}

$S$ sulphate; $N$ nitrate; $C f$ flooded control

over 14 weeks with the following stages: 2 weeks of acclimatization, 5 weeks of inundation, followed by 7 weeks without flooding.

Measurements and chemical analyses

Soil texture was determined based on Bouyoucos aereometric method (Plaster 1997) using a Soil Texture Diagram, water content by drying soil samples at $105^{\circ} \mathrm{C}(24 \mathrm{~h})$, and organic matter content by loss-on-ignition $\left(550^{\circ} \mathrm{C}, 4 \mathrm{~h}\right)$. Several soil extractions were performed on fresh soil samples, corrected afterwards for moisture content, to estimate levels of plant available $\mathrm{P}\left(5 \mathrm{~g}\right.$ soil in $100 \mathrm{ml}$ of $0.5 \mathrm{NaHCO}_{3}$; Olsen et al. 1954) and $\mathrm{N}(0.2 \mathrm{M} \mathrm{NaCl}$-extractableammonium and water-extractable nitrate, both $35 \mathrm{~g}$ soil in $100 \mathrm{ml}$ of extractant). The concentration of amorphous iron was estimated by oxalate extraction (2.5 g soil in the $30 \mathrm{ml}$ mixture of $\left(\mathrm{COONH}_{4}\right)_{2} \cdot \mathrm{H}_{2} \mathrm{O}$ and $\left(\mathrm{COOH}_{2}\right) \cdot 2 \mathrm{H}_{2} \mathrm{O}$; Schwertmann 1964). Finally, soil $\mathrm{P}$ fractions were estimated using the method described by Golterman (1996). In this sequential method, labile $\mathrm{P}\left(1 \mathrm{M} \mathrm{NH}_{4} \mathrm{Cl}\right), \mathrm{Fe}$ - and $\mathrm{Al}$-bound $\mathrm{P}$ (mixture of $0.05 \mathrm{M}$ Ca-EDTA, $\mathrm{CaCl}_{2}$ and Na-dithionite), and Ca-bound $\mathrm{P}$ (0.1 M Na-EDTA) fractions were extracted followed by acid digestion to estimate $\mathrm{P}$ bound to organic matter. In addition, total element concentrations were measured after digestion of $200 \mathrm{mg}$ samples in a mixture of concentrated $\mathrm{HNO}_{3}$ and $30 \% \mathrm{H}_{2} \mathrm{O}_{2}(4+1 \mathrm{ml})$ using a Milestone microwave MLS 1200 Mega system.

Soil Eh7 was determined using platinum wire electrodes $(n=5)$ and a glass $\mathrm{Ag} / \mathrm{AgCl}$ reference electrode at a depth of $5 \mathrm{~cm}$ below soil surface. Obtained values were corrected to the potential relative to the normal hydrogen reference electrode at $\mathrm{pH} 7$. 
In order to monitor soil water chemistry, two soil water samplers (Rhizon SMS-10 cm; Eijkelkamp Agrisearch Equipment, Giesbeek, The Netherlands) were placed diagonally between 5 and $10 \mathrm{~cm}$ depth in the soil of each container, and connected to black silicone tubes. Soil water was collected anaerobically using syringes $(50 \mathrm{ml})$ for vacuum suction. The first $10 \mathrm{ml}$ was discarded in order to remove internal stagnant water. Both subsamples were pooled and used for all required analyses. Surface water samples from each compartment were collected into $500 \mathrm{ml}$ polyethylene bottles. Samples were taken immediately after flooding, and after 1, 2, 4, 6 and 11 weeks for soil water, or after 1, 2 and 4 weeks for surface water.

The concentration of free sulphide in the soil water was estimated in $10.5 \mathrm{ml}$ of subsample fixed immediately after collection with $10.5 \mathrm{ml}$ of a sulphide antioxidant buffer (Van Gemerden 1984). For this measurement a sulphide ion-selective Ag-electrode and a double junction calomel reference electrode were used (Roelofs 1991).

Soil water $\mathrm{pH}$ was measured with a combined $\mathrm{pH}$ electrode (Orion Research, Beverly, CA, USA). Alkalinity of soil- and surface water was determined by titrating $10 \mathrm{ml}$ of sample with $0.01 \mathrm{M} \mathrm{HCl}$ down to a $\mathrm{pH}$ of 4.2 (TIM800 $\mathrm{pH}$-meter with the above mentioned pH-electrode and a ABU901 Autoburette, Radiometer Copenhagen, Denmark). The turbidity (NTU, Nephelometric Turbidity Units) of the surface water was estimated using a WTW turbidity meter Turb550 (Weilheim, Germany). The remaining volume was filtered over a Whatman microfiber filter type GF/C (Whatman, Brentford, UK), and, after the addition of citric acid to a final concentration of $0.125 \mathrm{~g} \mathrm{l}^{-1}$ to prevent precipitation of metals, stored in $100 \mathrm{ml}$ iodated polyethylene bottles at $-28^{\circ} \mathrm{C}$ until further analysis.

The concentrations of chloride, soluble reactive phosphorus (SRP), nitrate and ammonium were determined colorimetrically in all water samples using Auto Analyser 3 System (Bran + Luebbe, Norderstedt, Germany). SRP was analysed according to Henriksen (1965) with ammonium molybdate. Ammonium and nitrate were measured using, respectively, hydrazine sulphate (Kamphake et al. 1967) and salicylate (Grasshoff and Johannsen 1972) and chloride concentration using feriammonium sulphate (O'Brien 1962). The results were corrected for colour caused by humic substances (Shizmadzu UV-120-01 spectrophotometer, Kyoto, Japan, colour measured at $450 \mathrm{~nm}$ ) for soil water samples. The total concentrations of $\mathrm{Al}, \mathrm{Ca}, \mathrm{Mg}$, $\mathrm{Mn}, \mathrm{Fe}, \mathrm{K}, \mathrm{S}$, and $\mathrm{Zn}$ in soil water and surface water were analysed by means of inductively coupled plasma optical emission spectrometry (ICP-OES, IRIS Intrepid II, Thermo Electron Corporation, Franklin, MA, USA).

The concentrations of $\mathrm{CO}_{2}$ and $\mathrm{CH}_{4}$ were determined by collecting soil water samples into vacuumed infusion flasks $(30 \mathrm{ml})$ and correcting for the headspace volume. Gas concentrations were measured using infrared carbon analyser (0525 HR Oceanography International Analytical, College Station, TX, USA).

\section{Vegetation}

Total vegetation cover [\%] was estimated at the beginning and the end of the experiment, and individuals of each species were counted. Additionally, algae cover [\%] at the end of the flooding phase was determined.

\section{Data Analysis}

Obtained results were statistically processed by means of SPSS for Windows (SPSS 15.0, 2006, Chicago, IL, USA). For soil and water chemistry data, an $\ln (x+1)$ transformation was applied in order to make the data fit better to the normal distribution and to make the variances less dependent of the sample means. Vegetation cover and algae cover were arcsin sqrt transformed and species number was $\log (x+1)$ transformed.

Relationships between variables (only for flooded treatments during period of inundation, i.e., during 5 weeks) were tested by calculating Spearman's rho correlation coefficient $\left(r_{\mathrm{s}}\right)$ due to differences between sizes of variables, and regression lines were fitted. Asterisks indicate significance of correlations: $* p<0.05$, ** $p<0.01$, *** $p<0.001)$.

The repeated measures ANOVA mixed designs (GLM 5) procedure was used in order to test the effects of different water qualities (only flooded treatments were tested) during 1-month inundation for both tested meadows. If the assumption of sphericity was not met, an appropriate correction was used according to the values of the Greenhouse 
or Huynh-Feldt test statistics (Field 2005). Tukey HSD (homogeneity of variances assumed) or GamesHowell procedure (homogeneity of variances not assumed) were used as post hoc tests.

The effects of flooding itself in comparison with moist controls were tested performing one-way ANOVA (GLM 1) with Tukey or Games-Howell post hoc test for the last week of inundation. Differences between soil characteristics were assessed using independent samples $t$-test.

To test the impact of flooding on vegetation, we compared the means of values measured in moist $(\mathrm{Cm})$ and flooded $(\mathrm{Cfl})$ controls, whereas to test the effects of composition of flood water we used $\mathrm{Cfl}$ as a control treatment ( $\mathrm{Cm}$ was not included), using repeated measures mixed models analysis (GLM 5), except for algae cover where one-way ANOVA was applied. The same steps were taken to meet the assumptions (i.e., sphericity, post hocs).

Significance was accepted when the $p$-value was $\leq 0.05$. For better clarity, all data are presented as means of non-transformed variables \pm standard error of the mean (SEM).

\section{Results}

Changes in soil water

At the onset of the experiment the soil of all sods showed aerobic conditions $(\mathrm{Eh} 7=650 \mathrm{mV})$ with low levels of Fe, soluble reactive phosphorus (SRP) and ammonium, and an alkalinity below 1 meq $1^{-1}(\mathrm{pH}$ 6.0). Flooding led to anaerobic conditions (Eh7 $=105 \mathrm{mV}, p<0.001)$ in comparison to $\mathrm{Cm}$. The observed changes of the Eh7 in the flooded soils could be linked to reduction of $\mathrm{NO}_{3}$ (first 2 weeks, $\mathrm{Eh}>200 \mathrm{mV}$ ) followed by Fe reduction. When the water table was lowered again, Eh7 started to rise and returned to the initial values after 1 month of desiccation (Fig. 2). The alkalinity of the soil water had increased fivefold in all inundated treatments after 4 weeks (Fig. 2, $p<0.001$ ). The values for the moist control sods $(\mathrm{Cm})$ remained unchanged, and were significantly different from the flooded treatments $(p<0.001)$. There were no significant differences between $\mathrm{SN}, \mathrm{S}$ and $\mathrm{N}$ treatments for both soils $(p=0.23)$. The lowering of the water tables stopped this alkalinization process, and values returned to their
Fig. 2 Changes of selected parameters in both tested soils. Black squares represent treatment with both sulphate and nitrate addition ( $\mathrm{SN})$, gray squares sulphate alone (S), triangles nitrate alone $(\mathrm{N})$, open squares flooded controls (Cfl) and crosses moist controls $(\mathrm{Cm})$. Error bars represent the standard error of mean $(n=4)$

initial low levels equal to the moist control. Soil water $\mathrm{pH}$ varied between 5 and 6.7 , without differences among flooding treatments or between meadows (results not shown).

During the period of inundation, a significant $(p<0.001)$ increase of $\mathrm{CO}_{2}$ plus dissolved carbonates (total inorganic carbon, TIC) occurred in the soil water, ranging between 1,500 and $3,000 \mu \mathrm{mol} \mathrm{l}^{-1}$, whereas moist controls showed significantly lower values $(p<0.001)$. Lowering of the water table resulted in a fast, significant decrease to control levels (results not shown). During the whole period, there was hardly any methane detectable in the soil water, with exception of one small peak of 6-10 $\mathrm{mmol}^{-1}$ in the 6th week for $\mathrm{S}$ and $\mathrm{N}$ treatments.

At the beginning, levels of nitrate in the soil water ranged between 1,000-2,000 and 300-600 $\mu \mathrm{mol}^{-1}$ in PAS and HAY, respectively, for all treatments (Fig. 2). During inundation, concentrations of nitrate in the soil water dropped very fast to $1-20 \mu \mathrm{mol} 1^{-1}$, but after lowering of the water table at the end of the experiment nitrate showed a strong increase to high levels around 3,000 and 5,500 $\mu \mathrm{mol} 1^{-1}$ for the PAS and HAY meadows, respectively $(p<0.001)$. We observed differences in nitrate depletion: in PAS nitrate disappeared within 2 weeks whilst for HAY much lower concentrations were already reached after 1 week of the experiment.

At the end of the inundation period, ammonium levels in inundated sods were significantly higher than those measured in the moist controls $(p<0.001)$. Both meadows significantly differed in their response: HAY showed a much stronger increase than PAS (time and land use interaction, $p<0.001$, Table 3). One week after the water table was drawn down again the ammonium concentrations amounted to 600 and $1,200 \mu \mathrm{mol} \mathrm{l}^{-1}$ in PAS and HAY, respectively (Fig. 2; Table 3; $p<0.001$ ), after which they decreased to low values, equal to the controls.

Iron concentrations rose during flooding from around 10 to $400-450 \mu \mathrm{mol}{ }^{-1} 6$ weeks after the onset of the experiment (Fig. $2 ; p<0.001$ ), with 

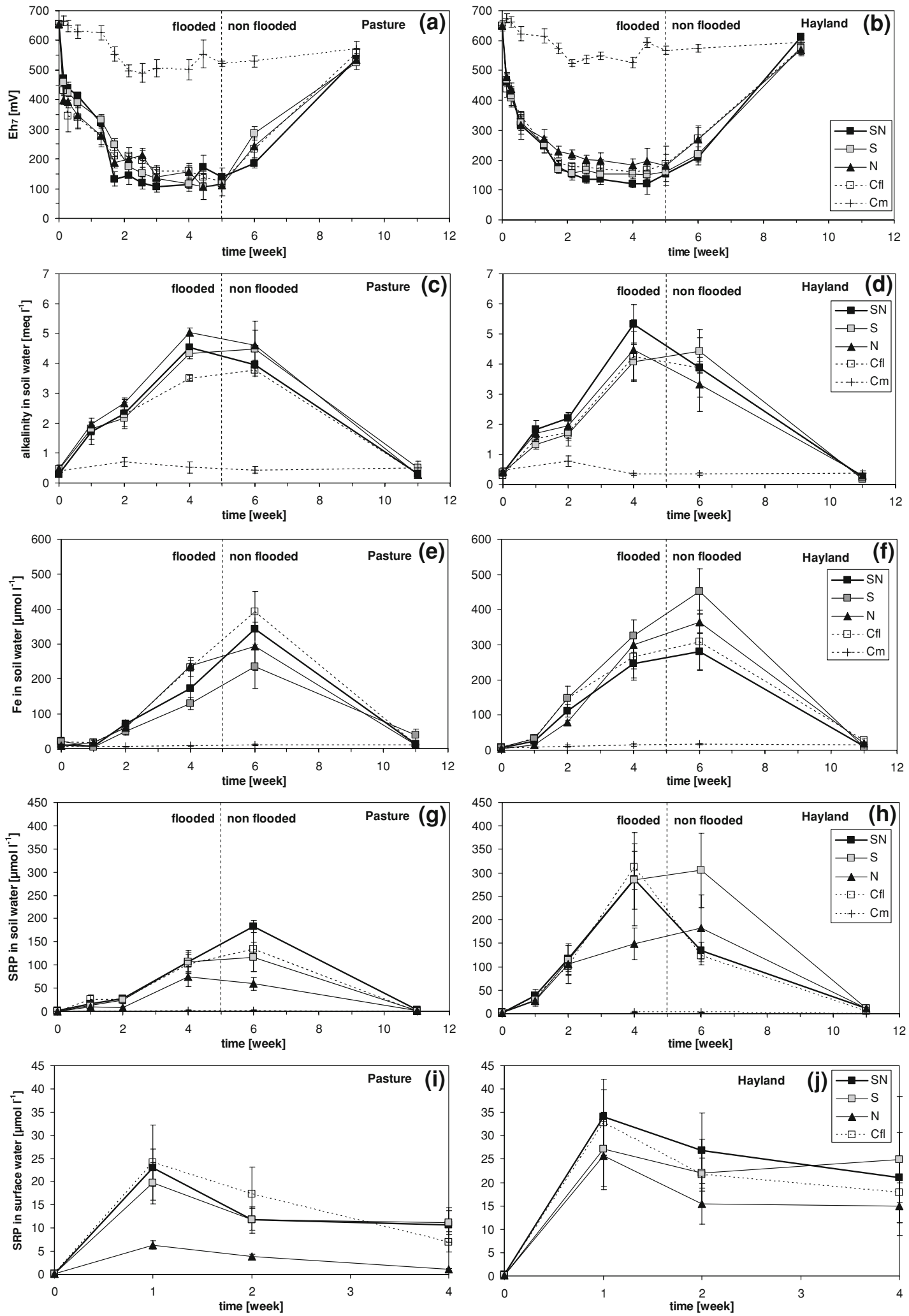

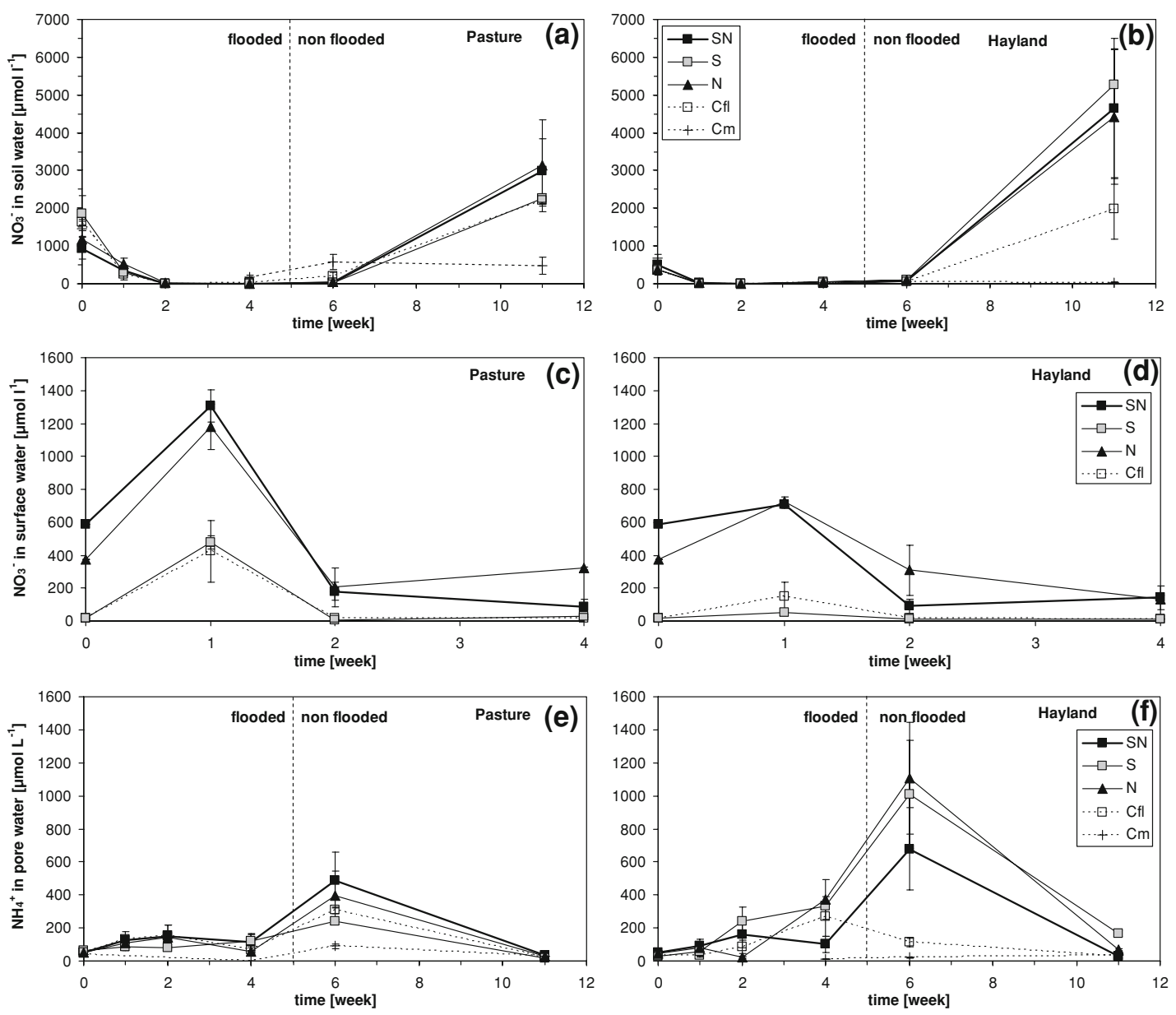

Fig. 2 continued

significantly higher concentrations of mobilized $\mathrm{Fe}$ for the hayland. Lowering of the water table resulted in $\mathrm{Fe}$ depletion of the soil water, and concentrations were comparable with moist controls after 6-11 weeks. These controls had significantly lower levels of mobilized iron $(p<0.001)$ in comparison to all flooded treatments.

SRP concentrations in the soil water increased strongly during flooding, showing a significant influence of the type of land use. Values for the hayland were twice as high as for the pasture (Fig. 2), indicated by significant time $\times$ land-use interaction and the effect of land use alone (both $p<0.001$ ). The highest SRP concentrations reached levels of 200$300 \mu \mathrm{mol} 1^{-1}$. There was, however, no significant effect of floodwater quality $(p=0.10)$. SRP was lower in moist controls compared to the flooded treatment $\left(1-3 \mu \mathrm{mol} 1^{-1}, p<0.001\right)$. The lag phase of P-mobilization for the pasture only started after 2 weeks whilst in the hayland it took place immediately after submergence (1st week, Fig. 2). After lowering the water table, the SRP concentrations further increased during the first week, but subsequently returned to moist control values. SRP concentrations were positively correlated with $\mathrm{Fe}$ $\left(r_{\mathrm{s}}=0.82^{* *}\right)$ and negatively with $\mathrm{NO}_{3}$ in soil water $\left(r_{\mathrm{s}}=-0.63^{* *}\right.$, Fig. 3$)$.

Sulphate levels in the soil water were significantly higher in the treatments where it was introduced $\left(1,400-1,500 \mu \mathrm{mol} 1^{-1}, p<0.001\right)$ for both soil types, and decreased to $200-600 \mu \mathrm{mol} \mathrm{l}^{-1}$ after 2 weeks of flooding, after nitrate had been depleted. After lowering the water table, sulphate increased to $850 \mu \mathrm{mol} \mathrm{l}^{-1}$ for the S and SN treatments (data not shown). Although 
Table 3 Results of time $(T)$ effects and their interactions with land use $(L)$, and treatment (Tr) for the flooded soils during the flooding period, examined by means of repeated measures mixed models analysis

\begin{tabular}{|c|c|c|c|c|c|c|c|}
\hline & Time $(T)$ & $T \times L$ & $T \times \operatorname{Tr}$ & $T \times L \times \operatorname{Tr}$ & $L$ & $\operatorname{Tr}$ & $L \times \operatorname{Tr}$ \\
\hline \multicolumn{8}{|c|}{ Soil (water) } \\
\hline Eh7 & $328.48 * * *$ & $3.44 *$ & $3.34 * *$ & $1.36^{\mathrm{NS}}$ & $0.17^{\mathrm{NS}}$ & $1.90^{\mathrm{NS}}$ & $0.35^{\mathrm{NS}}$ \\
\hline Alkalinity & $348.46 * * *$ & $1.77^{\mathrm{NS}}$ & $0.45^{\mathrm{NS}}$ & $0.27^{\mathrm{NS}}$ & $1.73^{\mathrm{NS}}$ & $1.53^{\mathrm{NS}}$ & $0.89^{\mathrm{NS}}$ \\
\hline $\mathrm{TIC}$ & $93.90 * * *$ & $1.19^{\mathrm{NS}}$ & $0.40^{\mathrm{NS}}$ & $0.56^{\mathrm{NS}}$ & $0.91^{\mathrm{NS}}$ & $1.26^{\mathrm{NS}}$ & $1.60^{\mathrm{NS}}$ \\
\hline $\mathrm{NO}_{3}^{-}$ & $271.16 * * *$ & $39.75 * * *$ & $3.49 * *$ & $1.78^{\mathrm{NS}}$ & $57.48 * * *$ & $4.96^{\mathrm{NS}}$ & $0.68^{\mathrm{NS}}$ \\
\hline $\mathrm{NH}_{4}^{+}$ & $8.34 * * *$ & $8.29 * * *$ & $1.40^{\mathrm{NS}}$ & $2.05^{*}$ & $1.34^{\mathrm{NS}}$ & $0.26^{\mathrm{NS}}$ & $0.33^{\mathrm{NS}}$ \\
\hline SRP & $363.76 * * *$ & $5.95 * *$ & $0.39^{\mathrm{NS}}$ & $0.83^{\mathrm{NS}}$ & $40.42 * * *$ & $2.32^{\mathrm{NS}}$ & $0.33^{\mathrm{NS}}$ \\
\hline $\mathrm{Fe}$ & $351.39 * * *$ & $18.05 * * *$ & $1.15^{\mathrm{NS}}$ & $1.27^{\mathrm{NS}}$ & $11.98 * *$ & $1.16^{\mathrm{NS}}$ & $2.08^{\mathrm{NS}}$ \\
\hline $\mathrm{SO}_{4}{ }^{2-}$ & 83.11*** & $5.82 *$ & $5.24 * *$ & $0.24^{\mathrm{NS}}$ & $1.25^{\mathrm{NS}}$ & $22.17 * * *$ & $2.50^{\mathrm{NS}}$ \\
\hline $\mathrm{H}_{2} \mathrm{~S}$ & $89.23 * * *$ & $\mathrm{NC}$ & $1.58^{\mathrm{NS}}$ & $\mathrm{NC}$ & $\mathrm{NC}$ & $8.45 * *$ & $\mathrm{NC}$ \\
\hline \multicolumn{8}{|c|}{ Surface water } \\
\hline Turbidity & $223.76 * * *$ & $0.04^{\mathrm{NS}}$ & $0.81^{\mathrm{NS}}$ & $2.86^{*}$ & $0.20^{\mathrm{NS}}$ & $0.41^{\mathrm{NS}}$ & $0.84^{\mathrm{NS}}$ \\
\hline $\mathrm{NO}_{3}{ }^{-}$ & $68.16 * * *$ & $6.13 * *$ & $3.63 * *$ & $2.23 *$ & $3.58^{\mathrm{NS}}$ & $67.88 * * *$ & $0.98^{\mathrm{NS}}$ \\
\hline $\mathrm{NH}_{4}^{+}$ & $141.30^{* * * *}$ & $4.52 *$ & $14.70 * * *$ & $1.19^{\mathrm{NS}}$ & $20.47 * * *$ & $17.72 * * *$ & $0.95^{\mathrm{NS}}$ \\
\hline SRP & $269.39 * * *$ & $5.67 * *$ & $1.96^{\mathrm{NS}}$ & $0.79^{\mathrm{NS}}$ & $13.68 * *$ & $3.56 *$ & $1.22^{\mathrm{NS}}$ \\
\hline $\mathrm{Fe}$ & $180.22 * * *$ & $5.13 * *$ & $3.40 * *$ & $2.68 *$ & $0.34^{\mathrm{NS}}$ & $5.65 * *$ & $4.18 *$ \\
\hline $\mathrm{SO}_{4}{ }^{2-}$ & $70.35 * * *$ & $2.34^{\mathrm{NS}}$ & $15.42 * * *$ & $1.02^{\mathrm{NS}}$ & $0.16^{\mathrm{NS}}$ & $379.68 * * *$ & $0.22^{\mathrm{NS}}$ \\
\hline
\end{tabular}

$F$-ratios and their levels of significance are given $(n=4)$. $p<0.05 ; * * p<0.01 ; * * * p<0.001 ; N S$ non-significant, NC not calculated due to missing data. Bold values indicate significant differences

Eh7 values stayed above $0 \mathrm{mV}$, we measured some sulphide in the soil water, at very low concentrations with maximum values of about $4 \mu \mathrm{mol}{ }^{-1}$ (sulphate enriched waters) after 5 weeks of inundation. Sulphide concentrations stayed low $\left(<1 \mu \mathrm{mol} \mathrm{l^{-1 }}\right)$ in treatments without sulphate addition. Significant differences were noted only for the $\mathrm{SN}$ treatment in comparison with the treatments without sulphate addition $(p<0.01$, Table 3). It was clear, however, that sulphide concentrations were strongly, positively $\left(r_{\mathrm{s}}=0.80^{* *}\right)$ correlated with SRP in soil water.

\section{Changes in surface water}

Flooding resulted in a strong, significant increase of the turbidity of the surface water in all treatments, from values around 2 to maximum values around 12 NTU (data not shown, $p<0.001$ ), without differences between treatments or land use. The alkalinity increased slowly during 5 weeks of inundation from 2.5 to 3.5 meq $1^{-1}$ and $\mathrm{pH}$ varied between 7.1 and 7.6, both without differences between treatments (data not shown). Changes in water turbidity were correlated with alkalinity $\left(r_{\mathrm{s}}=0.77 * *\right), \operatorname{SRP}\left(r_{\mathrm{s}}=0.70^{* *}\right)$, sulphide $\left(r_{\mathrm{s}}=0.60^{* *}\right)$ and iron $\left(r_{\mathrm{s}}=0.59^{* *}\right)$ in soil water. Turbidity also correlated with concentrations of $\operatorname{SRP}\left(r_{\mathrm{s}}=0.56^{* *}\right)$ and iron $\left(r_{\mathrm{s}}=0.52 * *\right)$ in the surface water.

Nitrate concentrations decreased strongly after 2 weeks of inundation and remained below the added concentration of $1 \mathrm{mmol}^{-1}$ until the end of the flooding period, at the through-flow speed used (maximum values $200-400 \mu \mathrm{mol}{ }^{-1}$, Fig. $2 ; p<0.001$ ). Concentrations were higher in the nitrate treatments ( $p<0.001$, Table 3 ) compared to the other treatments, which resulted in the interactions presented in Table 3. Sulphate concentrations in the surface water, in contrast, remained more or less at the added level (results not shown). The concentration of this ion in the water layer was not correlated with other factors.

Ammonium decreased over time, from 100-150 to $50 \mu \mathrm{mol}^{-1}$ and lower values $(p<0.001)$. We observed differences due to water quality and type of land use (both $p<0.001$ ). The highest levels in the surface water were measured in the $\mathrm{N}$ treatment, followed by the $\mathrm{SN}$ treatment, and the lowest for $\mathrm{S}$ 

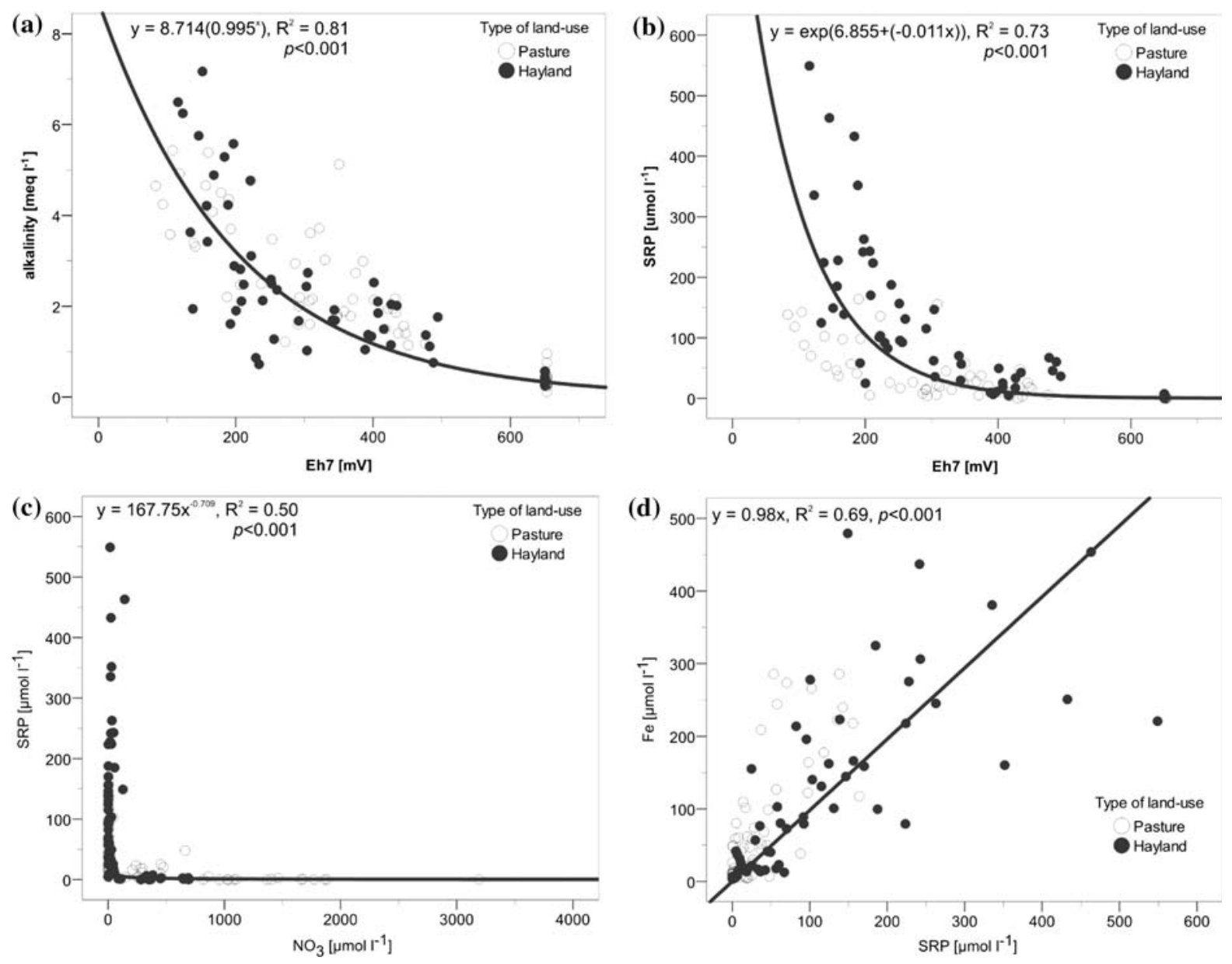

Fig. 3 Relation between redox potential corrected to $\mathrm{pH} 7$ (Eh7) and alkalinity (a) and phosphate (b), between nitrate and phosphate concentrations (c), and between iron and phosphate

(d) in soil water during inundation $(n=128)$. Open symbols represent pasture, closed hayland

and Cfl treatments (data not shown). PAS soils had significantly higher ammonium levels in the surface water than HAY soils.

There was a strong phosphate mobilization from the soil to the overlying water layer after 1 week, with very high concentrations of SRP in the range of 20-35 $\mu \mathrm{mol} 1^{-1}$, and subsequently showing a decreasing trend $(p<0.001)$. The lowest mobilization took place in the $\mathrm{N}$ treatments, especially in PAS sods (5-25 $\mu \mathrm{mol}^{-1}$, Fig. 2), for which it was significantly lower in comparison to the SN treatment $(p<0.05)$. The HAY soils showed significantly higher P mobilization to the water layer than the PAS soils $(p<0.01$, Table 3$)$. This process was accompanied by iron release (up to $15 \mu \mathrm{mol} 1^{-1}, p<0.001$ ). The

strongest $\mathrm{Fe}$ mobilization occurred in the treatments with sulphate (data not shown), which was significantly different from the $\mathrm{N}$ treatment $(p<0.001)$.

\section{Vegetation changes}

The comparison of the moist controls $(\mathrm{Cm})$ and flooded controls $(\mathrm{Cfl})$ showed that the partial submergence of the terrestrial vegetation resulted in a significant decrease $(50-90 \%)$ of the vegetation cover as a result of flooding ( $p<0.001$, results not shown), without differences between the different groups. The percentages decrease (compared to the initial values) ranged between 50 and $85 \%$ after 6 weeks of the experiment (results not shown). 


\section{Discussion}

Effects of inundation on biogeochemistry

Flooding affected soil microbial processes involved in element cycling thereby changing the redox state of the soil (Laanbroek 1990). Although oxygen is rapidly depleted, organic matter breakdown will still continue during flooding, coupled to the reduction of alternative electron acceptors (Gliński and Stępniewski 1985). The concomitant mobilization of nutrients such as phosphate, ammonium and iron was shown to be largely dependent on preexisting soil nutrient status, interacting to some extent with water quality (Lamers et al. 2001, Loeb et al. 2007).

The most drastic effect of inundation was the eutrophication of soil and surface water with phosphate (SRP) in all flooding treatments for both soils, causing strong development of filamentous algae (up to $20-80 \%$ of the compartment surface). Other studies (Boon 2006; Aldous et al. 2007) have shown that there may already be an immediate release of $P$ within the first $48 \mathrm{~h}$ of flooding due to redox processes or microbial lysis. There was a significant interaction with the concentration of Olsen P, as HAY showed a much stronger response in algal development than PAS $(p<0.05)$. Unexpectedly, the quality of the flooding water turned to be less important than this redox process related to iron reduction and concomitant $\mathrm{P}$ mobilization.

This type of eutrophication resulting from increased mobilization within the system and not from increased influx of nutrients, is called internal eutrophication. The phenomenon has been well described for fens and floodplains (e.g., Roelofs 1991; Lamers et al. 1998; 2002; Smolders et al. 2006; Loeb et al. 2007). In our experiment, redox related processes (particularly iron reduction; Stępniewski et al. 2005; Smolders et al. 2006) appeared to be the main driver of eutrophication. The mobilization of phosphate in the soil water turned out to be very high, but started only after depletion of nitrate, being the most favourable electron acceptor under anoxic conditions. This depletion was caused by nitrate reduction (denitrification, and possibly also dissimilatory nitrate reduction to ammonium, DNRA) and plant uptake. Interactions among nitrate, iron and phosphorus cycling can explain this phenomenon. In nitrate-poor soils, iron reduction leads to $\mathrm{P}$ mobilization from iron binding sites (Lucassen et al. 2004). In addition, decomposition may have contributed to the observed eutrophication, as inorganic carbon compounds accumulated due to anaerobic decomposition and accumulation.

The higher level of eutrophication for the hayland appeared to be related to higher Olsen-P and Fe/Albound $\mathrm{P}$ concentrations, most probably resulting from stronger fertilization. However, both meadows showed high concentrations of accumulated plant available $\mathrm{P}$, exceeding the reference value of $250 \mu \mathrm{mol}$ Olsen-P $1^{-1}$ DW for unfertilized soils (Lamers et al. 2006; Smolders et al. 2008). This means that the pasture had also been fertilized in the past. Such high values have also been found both in former and in present agricultural and riverine areas (Lamers et al. 2006; Loeb et al. 2007). Loeb et al. (2008b) showed that the rate of phosphate mobilization in floodplain soils could be predicted by the phosphate saturation of the iron binding sites in the soil, reflected by the pool of amorphous iron. In the present experiment, both soils were characterized by equal concentrations of both amorphous and total iron (as was expected for adjacent pastures), but differed in their $\mathrm{P}$ saturation values. In addition, the labile $\mathrm{P}$ fraction had significantly greater values for the hayland soil (Table 1). Several studies showed that phosphate sorption to iron and iron (hydr)oxides is of major importance in the redox-related phosphate kinetics of flooded soils, in contrast to calcium bound P (Patrick and Khalid 1974; Zak et al. 2004; Loeb et al. 2007). There was no difference for Ca-bound $\mathrm{P}$ between PAS soil and HAY soil. Although calcium may play a role in $\mathrm{P}$ immobilization after its release, we did not find differences between soils and treatments.

The ratio of $\mathrm{Fe}$ and $\mathrm{P}$ in the soil may be used as an indicator of $\mathrm{P}$ saturation. Other studies showed threshold values of $8-12 \mathrm{~mol} \mathrm{~mol}^{-1}$ for total sediment ratios, below which $\mathrm{P}$ mobilization strongly increased (Jensen et al. 1992; Ramm and Scheps 1997). We found average values around 12 for total $\mathrm{Fe}: \mathrm{P}$, indicating that $\mathrm{P}$ mobilization from $\mathrm{Fe}$ is very likely, even though the concentration of Fe/Al-bound $\mathrm{P}$ is much lower than that of total $\mathrm{P}$. The concomitant release of $\mathrm{Fe}$ and $\mathrm{P}$ in soil water during inundation still suggests that Fe bound $\mathrm{P}$ was released. Furthermore, a large fraction of $\mathrm{Fe}$ in the soil seems to be bound to sulphur $\left(\mathrm{FeS}_{x}\right)$ and is therefore not available for Pbinding; the ratio between (Fe minus $\mathrm{S}$ ) and $\mathrm{P}$ is 6-7. Another indicator of phosphate release to the surface water may be the $\mathrm{Fe}: \mathrm{PO}_{4}$ ratio in the soil water. 
Several authors (Smolders et al. 2001; Zak et al. 2004; Geurts et al. 2008) showed that values lower than 1-3 $\left(\mathrm{mol} \mathrm{mol}^{-1}\right)$ in the anaerobic soil water corresponded to strong $\mathrm{PO}_{4}$ release from the soil to the surface water. In our experiment, we found the same correlation between this ratio and phosphate (SRP) levels in the surface water. Iron precipitation at the soil surface may have been hindered either through partially anoxic conditions or due to stable dissolved $\mathrm{Fe}-(\mathrm{P})$ humic complexes. The ratios differed between soils and treatments; HAY showed significantly lower values $(p<0.05)$. The initial ratios between Fe and $\mathrm{P}$ in the soil water were, however, around 14 (ranging between 5 and 22), which is higher than the threshold values mentioned above. This can probably be explained by the fact that the soil water was aerated before flooding, unlike the other studies. The results, taken together, indicate that iron reduction and $\mathrm{P}$ saturation may have been important factors to explain the observed phosphate eutrophication. This was also demonstrated by the strongly significant correlation between iron and SRP in the soil water $\left(r_{\mathrm{s}}=0.82 * * *\right.$, $\left.R^{2}=0.65\right)$. In addition to this mechanism, the release of microbially bound P (Turner and Haygarth 2001) may also be involved.

\section{Limited role of surface water quality}

When the supply of nitrate is high, phosphate mobilization as a result of iron reduction may not occur, as nitrate is a more favourable electron acceptor than Fe. Surprisingly, we did not observe lower iron mobilization rates (which should have been indicated by lower iron concentrations) as a result of additional nitrate supply, as was found in fens into which nitrate rich groundwater discharged (Lucassen et al. 2004). Although chloride values in soil water showed full infiltration after 2 weeks of flooding (results not shown), this was probably caused by the much lower infiltration rate into the soil in the present experiment during flooding. This indicates that the local hydrological conditions play a significant role interacting with water quality. High nitrate concentrations in the surface water could, therefore, not prevent phosphate (SRP) mobilization in the soil water in this experiment, although the concentrations in the $\mathrm{N}$ only treated soils tended to be slightly lower. However, phosphate release from the soil to the surface water was clearly lower for the nitrate only treated soils (particularly for
PAS), probably as a result of a higher redox potential in the upper layer of the soil due to nitrate reduction. Simultaneous addition of sulphate, however, nullified this effect.

Nitrate addition alone $(\mathrm{N})$ did, however, result in a significantly higher redox potential in comparison with treatments where sulphate was introduced ( $\mathrm{S}$ and $\mathrm{SN}$ ), mainly for the hayland soils, as it is a more favourable electron acceptor than sulphate and therefore has a higher Eh7. Ammonium concentrations in soil water increased slowly, being more visible in the HAY soil, which may have resulted from mineralization (correlation with alkalinity generated by anaerobic decomposition, $r_{\mathrm{s}}=0.41^{* *}$, $R^{2}=0.31$ ), from nitrate reduction via DNRA (Hefting et al. 2004) or from increased iron reduction rates (Scherer and Zhang 1999).

Sulphate addition led to high concentrations in soil water during the first weeks. However, we observed a rapid decrease to 200-600 $\mu \mathrm{mol} \mathrm{l}^{-1}$ (results not shown) by the end of the inundation period due to sulphate reduction in the absence of more favourable electron acceptors. This was possibly stimulated by the increased alkalinity (Roelofs 1991), generated during reduction of different oxidants (Smolders et al. 2006; Loeb et al. 2007). Increased soil alkalinization in wet soils may result in higher nutrient mobilization rates due to stronger $\mathrm{pH}$ buffering of organic matter (Smolders et al. 2006). In nitrate-poor soils, increased sulphate reduction rates due to sulphate pollution of the surface water may lead to $\mathrm{FeS}_{x}$ formation and subsequent $\mathrm{P}$ mobilization form iron binding sites (Caraco et al. 1989; Roelofs 1991; Lamers et al. 1998; Smolders et al. 2006; Zak et al. 2006). However, due to the high availability of iron in the soils tested, additional sulphate reduction was not able to mobilize additional $\mathrm{P}$, as was also shown for other floodplain soils (Loeb et al. 2007). During sulphate reduction, concentrations of produced sulphide in the soil water stayed very low due to binding to iron, which was highly available, and became only slightly higher at the end of the inundation period.

Lowering of the water table after the flooding

Water removal caused an increase of aeration state of the soils by oxygen intrusion as showed by the gradual return of the Eh7 to the pre-flooding values. Ammonium initially showed a very strong increase, 
especially in the hayland where values were similar to those reported by Loeb et al. (2007) for an alder carr. This is most probably caused by proton production due to the oxidation of iron and iron sulphides, which leads to mobilization of ammonium from cation exchange sites in the soil. Although the concentrations became very high, it is unlikely that the concentration of ammonium became phytotoxic because the $\mathrm{pH}$ stayed sufficiently high (De Graaf et al. 1998; Lucassen et al. 2003; Van den Berg et al. 2005). The acidification was indicated by the consumption of alkalinity (Lucassen et al. 2002; Smolders et al. 2006). There appeared to be sufficient acid neutralising capacity to prevent a drop in $\mathrm{pH}$ values, which could also be predicted by total $\mathrm{S} /(\mathrm{Ca}+\mathrm{Mg})$ ratios, which were lower than 0.7 (Lucassen et al. 2002). Due to the prevention of low $\mathrm{pH}$ values, levels of potentially toxic metals other than Fe remained very low (results not shown).

Five weeks after the water table was drawn down, soil conditions were comparable to those before inundation. As a result of iron oxidation, $\mathrm{P}$ was immobilized and concentrations became comparable to those in the moist controls $(\mathrm{Cm})$. Accumulated ammonium was rapidly nitrified leading to extremely high levels of nitrate $\left(3,000-5,000 \mu \mathrm{mol} \mathrm{l}^{-1}\right)$. The differences between $\mathrm{NO}_{3}$ concentrations among tested soils were related to ammonium concentrations. This increased availability of nitrogen may, on the longer term, also lead to changes in vegetation composition.

\section{Effects on vegetation}

Five weeks of flooding caused a temporary decrease of vegetation cover and biodiversity, presumably due to the combined effect of flooding and competition with algae. Herb species suffered most from flooding, regardless the water quality. For the pasture, this led to a relatively increased dominance of sedge species (results not shown). Although the vegetation partly recovered after the flooding period, its cover was still lower than initially, and the species composition had changed as a result of flooding stress which is well known for flooding of terrestrial species (Banach et al. 2009).

\section{Conclusions}

Our work showed the interacting effects of summer inundation, when biogeochemical process rates are higher than during winter flooding (Loeb et al. 2008a), and agricultural use. From this study, it is clear that the temporal inundation of fertilized floodplains will lead to increased nutrient mobilization, particularly for phosphate. The type of land use plays a significant role, as it determines the level of nutrient loading leading to differential responses. In addition, floodplains become a strong source of phosphate, deteriorating river water quality. After flooding, nitrate accumulates to high levels, with possible additional effects on biodiversity on the longer term.

The composition of the floodwater appeared, at least for the treatments tested, to be of less importance on the short term, as the main effects occurred due to the anoxic conditions. There are, however, uncertainties surrounding effects of floodwater quality that warrant further study of local hydrology during flood events. Although the influx of nitrate may hamper $\mathrm{P}$ mobilization by preventing $\mathrm{Fe}$ and sulphate reduction, it can also stimulate decomposition and mineralization, leading to ammonium accumulation. The concentration of sulphate did not have severe effects, as the concentrations of amorphous iron were high enough to sequester most sulphide and prevent additional $\mathrm{P}$ mobilization or accumulation of sulphide in the soil water.

Our study indicates that the increased risk of summer flooding in Eastern Europe during last years due to climate change increases the risk of eutrophication to a great extent. This may have significant effects on river water composition, as the SRP concentrations in the flood water increased to 15-20 $\mu \mathrm{mol} 1^{-1}$, which is much higher than the average concentration in the Chodelka River, being $2 \mu \mathrm{mol} 1^{-1}$. Based on these values, the $\mathrm{P}$ mobilization to the water layer amounted to $0.24-0.32 \mathrm{mmol}$ (7.4-9.9 mg P) m $\mathrm{m}^{-2} \mathrm{day}^{-1}$. The actual effect of these high mobilization rates on river water quality will, however, depend on the water flux in the field, sedimentation of $\mathrm{P}$ and dilution with river water. The risk of eutrophication appears to be significant for highly fertilized fields without additional measures such as the removal of the nutrient rich top soil (Lamers et al. 2006). Eutrophication of river water and floodplain wetlands is expected to lead to undesired dominance of algae and cyanobacteria, loss of aquatic macrophytes, and lower oxygen concentrations, affecting biodiversity and human health (drinking water, 
recreation). Our results imply that this potentially high contribution to eutrophication of riverine areas, as shown by soil analysis, has to be taken into account when floodplains are selected for combined water storage and wetland rehabilitation (floodplain reconnection), particularly during the growing season when the rates of biogeochemical transformations are higher.

Acknowledgments We would like to thank Werner van Eck for his help to collect and transport the sods to The Netherlands. In addition, we like to acknowledge Fons Smolders, Marlies van der Welle, Roos Loeb, Jeroen Geurts, Hilde Tomassen and Josef Stuefer for technical assistance and valuable comments on an earlier version of this manuscript.

Open Access This article is distributed under the terms of the Creative Commons Attribution Noncommercial License which permits any noncommercial use, distribution, and reproduction in any medium, provided the original author(s) and source are credited.

\section{References}

Aldous AR, Craft CB, Stevens CJ, Barry MJ, Bach LB (2007) Soil phosphorous release from a restoration wetland, Upper Klamath Lake, Oregon. Wetlands 27(4):1025-1035. doi: 10.1672/0277-5212(2007)27[1025:SPRFAR]2.0.CO;2

Banach K, Banach A, Lamers LPM, De Kroon H, Bennicelli RP, Visser EJW (2009) Differences in flooding tolerance between species from two wetland habitats with contrasting hydrology-implications for vegetation development in future floodwater retention areas. Ann Bot (Lond) 103:341-351. doi:10.1093/aob/mcn183

Boon PI (2006) Biogeochemistry, ecology and management of hydrologically dynamic wetlands. In: Batzer DP, Sharitz RR (eds) The ecology of freshwater and estuarine wetlands. University of California Press, Berkely, pp 115-176

Bronstert A (2003) Floods and climate change: interactions and impacts. Risk Anal 23(3):545-557. doi:10.1111/1539-6924. 00335

Caraco NF, Cole JJ, Likens GE (1989) Evidence for sulphatecontrolled phosphorous release from sediments of aquatic systems. Nature 341:316-318. doi:10.1038/341316a0

De Graaf MCC, Bobbink R, Roelofs JGM, Verbeek PJM (1998) Differential effects of ammonium and nitrate on three heathland species. Plant Ecol 135(2):185-196. doi: 10.1023/A: 1009717613380

EEA (2007) Climate change and water adaptation issues. Technical report No 2/2007, European Environmental Agency, ISSN 1725-2237. http://reports.eea.europa.eu. Accessed 1 Feb 2008

Field A (2005) Discovering statistics using SPSS. SAGE Publications, London

Gemerden Van (1984) The sulphide affinity of phototrophic bacteria in relation to the location of elemental sulphur. Arch Mikrobiol 139:289-294
Geurts JJM, Smolders AJP, Verhoeven JTA, Roelofs JGM, Lamers LPM (2008) Sediment Fe: $\mathrm{PO}_{4}$ ratio as a diagnostic and prognostic tool for the restoration of macrophyte biodiversity in fen waters. Freshw Biol 53:2101-2116. doi: 10.1111/j.1365-2427.2008.02038.x

Gliński J, Stępniewski W (1985) Soil aeration and its role for plants. CRC Press Inc, Boca Raton

Golterman HL (1996) Fractionation of sediment phosphate with chealating compounds: a simplification, and comparison with other methods. Hydrobiologia 335:87-95. doi:10.1007/BF00013687

Grasshoff K, Johannsen H (1972) A new sensitive and direct method for the automatic determination of ammonia in sea water. J Cons Int Explor Mer 34(3):516-521

Hartig EK, Grozev O, Rosenzweig C (1997) Climate change, agriculture and wetlands in Eastern Europe: vulnerability, adaptation and policy. Clim Change 36:107-121. doi: 10.1023/A: 1005304816660

Hefting M, Clément JC, Dowrick D, Cosandey AC, Bernal S, Cimpian C, Tatur A, Burt TP, Pinay G (2004) Water table elevation controls on soil nitrogen cycling in riparian wetlands along a European climatic gradient. Biogeochemistry 67:113-134. doi:10.1023/B:BIOG.0000015320.69868.33

Henriksen A (1965) An automated method for determining lowlevel concentrations of phosphate in fresh and saline waters. Analyst (Lond) 90:29-34. doi:10.1039/an9659000029

Jensen HS, Kristensen P, Jeppesen E, Skytthe A (1992) Iron:phosphorus ratio in surface sediment as an indicator of phosphate release from aerobic sediments in shallow lakes. Hydrobiologia 235/236:731-743. doi:10.1007/BF00026261

Kamphake LJ, Hannah SA, Cohen JM (1967) Automated analysis for nitrate by hydrazine reduction. Water Res 1:205-206. doi:10.1016/0043-1354(67)90011-5

Kundzewicz ZW (2005) Intense precipitation and high river flows in Europe-observations and projections. Acta Geophysica Pol 53(4):385-400

Kundzewicz ZW, Ulbrich U, Brücher T, Graczyk D, Krüger A, Leckebusch GC, Menzel L, Pińskwar I, Radziejewski M, Szwed M (2005) Summer floods in Central Europe-climate change track? Nat Hazards 36:165-189. doi: 10.1007/s11069-004-4547-6

Kuźniar P, Popek Z, Żelazo J (2002) Analysis of the possibilities and needs of the river regulation activities in the middle Vistula River area of high values of the natural environment. Paper presented at the 5th international conference on Hydro-Science \& -Engineering, Warsaw, 18-21 September 2002

Laanbroek HJ (1990) Bacterial cycling of minerals that affect plant growth in waterlogged soils: a review. Aquat Bot 38:109-125. doi:10.1016/0304-3770(90)90101-P

Lamers LPM, Tomassen HBM, Roelofs JGM (1998) Sulphateinduced eutrophication and phytotoxicity in freshwater wetlands. Environ Sci Technol 32:199-2005. doi: 10.1021/es970362f

Lamers LPM, Dolle GET, van den Berg STG, van Delft SPJ, Roelofs JGM (2001) Differential responses of freshwater wetland soils to sulphate pollution. Biogeochemistry 55:87-102. doi:10.1023/A:1010629319168

Lamers LPM, Falla SJ, Samborska EM, van Dulken IAR, van Hengstum G, Roelofs JGM (2002) Factors controlling the 
extent of eutrophication and toxicity in sulphate-polluted freshwater wetlands. Limnol Oceanogr 47:585-593

Lamers LPM, Loeb R, Antheunisse AM, Miletto M, Lucassen ECHET, Boxman AW, Smolders AJP, Roelofs JGM (2006) Biogeochemical constraints on the ecological rehabilitation of wetland vegetation in river floodplains. Hydrobiologia 565:165-186. doi:10.1007/s10750-0051912-8

Linnerooth-Bayer J, Amendola A (2003) Introduction to special issue on flood risks in Europe. Risk Anal 23(3): 537-543. doi:10.1111/1539-6924.00334

Loeb R, van Daalen E, Lamers LPM, Roelofs JGM (2007) How soil characteristics and water quality influence the biogeochemical response to flooding in riverine wetlands. Biogeochemistry 85:289-302. doi:10.1007/s10533-0079135-x

Loeb R, Lamers LPM, Roelofs JGM (2008a) Effects of winter versus summer flooding and subsequent desiccation on soil chemistry in a riverine hay meadow. Geoderma 125:84-90. doi:10.1016/j.geoderma.2008.02.009

Loeb R, Lamers LPM, Roelofs JGM (2008b) Prediction of phosphate mobilisation in inundated floodplain soils. Environ Pollut 156:325-331. doi:10.1016/j.envpol.2008.02. 006

Lucassen ECHET, Smolders AJP, Roelofs JGM (2000) Increased groundwater levels cause iron toxicity in Glyceria fluitans (L.). Aquat Bot 66:321-327. doi:10.1016/ S0304-3770(99)00083-2

Lucassen ECHET, Smolders AJP, Roelofs JGM (2002) Potential sensitivity of mires to drought, acidification and mobilisation of heavy metals: the sediment $\mathrm{S} /(\mathrm{Ca}+\mathrm{Mg})$ ratio as diagnostic tool. Environ Pollut 1210:635-646

Lucassen ECHET, Bobbink R, Smolders AJP, van der Ven PJM, Lamers LPM, Roelofs JGM (2003) Interactive effects of low $\mathrm{pH}$ and high ammonium levels responsible for the decline of Cirsium dissectum (L.) Hill. Plant Ecol 165:45-52. doi:10.1023/A:1021467320647

Lucassen ECHET, Smolders AJP, van der Salm AL, Roelofs JGM (2004) High groundwater nitrate concentrations inhibit eutrophication of sulphate-rich freshwater wetlands. Biogeochemistry 67:249-267. doi:10.1023/B:BIOG.000 0015342.40992.cb

Mitchell JK (2003) European river floods in a changing world. Risk Anal 23(3):567-574. doi:10.1111/1539-6924.00337

Moore PA Jr, Reddy KR (1994) Role of Eh and pH on phosphorus geochemistry in sediments of lake Okeechobee, Florida. J Environ Qual 23:955-964

Nienhuis PH, Buijse AD, Leuven RSEW, Smits AJM, de Nooij RJW, Samborska EM (2002) Ecological rehabilitation of the lowland basin of the river Rhine (NW Europe). Hydrobiologia 478:53-72. doi:10.1023/A:1021070428566

O'Brien JE (1962) Automation in sanitary chemistry part 4: automatic analysis of chloride in sewage. Wastes Eng 33:670-682

Olsen SR, Cole CV, Watanabe FS, Dean LA (1954) Estimation of available phosphorous in soils by extraction with sodium bicarbonate. U.S. Dep. of Agric. Circ. 939, Washington, DC

Patrick WH, Khalid RA (1974) Phosphate release and sorption by sediments soils and sediments-effect of aerobic and anaerobic conditions. Science 186:53-55. doi:10.1126/ science.186.4158.53
Plaster EJ (1997) Soil science and management, 3rd edn. Delmar, New York

Ramm K, Scheps V (1997) Phosphorous balance of a polytrophic shallow lake with the consideration of phosphorous release. Hydrologia 342:43-53

Roelofs JGM (1991) Inlet of alkaline river water into peaty lowlands: effects on water quality and Stratiotes aloides L. stands. Aquat Bot 39:267-293. doi:10.1016/0304-3770(91) 90004-O

Scherer HW, Zhang Y (1999) Studies on the mechanisms of fixation and release of ammonium in paddy soils after flooding. I. Effect of iron oxides on ammonium fixation. J Plant Nutr Soil Sci 162:593-597. doi:10.1002/(SICI)15222624(199912)162:6<593::AID-JPLN593>3.0.CO;2-L

Schwertmann U (1964) Differenzierung der Eisenoxide des Bodes durch photochemishe Extration mit saurer Ammoniumoxalat-Loesung. Zeitschrift für Pflanzenernährung. Dungung Bodenkunde 105:194-202. doi:10.1002/jpln. 3591050303

Smits AJM, Nienhuis PH, Leuven RSEW (eds) (2000) New approaches to river management. Backhuys Publishers, Leiden

Smolders AJP, Lamers LPM, Moonen M, Zwaga K, Roelofs JGM (2001) Controlling phosphate release from phosphateenriched sediments by adding various iron compounds. Biogeochemistry 54:219-228. doi:10.1023/A:101066040 1527

Smolders AJP, Lamers LPM, Lucassen ECHET, van der Velde G, Roelofs JGM (2006) Internal eutrophication: how it works and what to do about it-a review. Chem Ecol 22:93-111. doi:10.1080/02757540600579730

Smolders AJM, Lucassen ECHET, van der Aalst M, Lamers LPM, Roelofs JGM (2008) Decreasing the abundance of Juncus effusus on former agricultural lands with noncalcareous sandy soils: possible effects of liming and soil removal. Restor Ecol (in press). doi:10.1111/j.1526-100X. 2007.00267.x

Snowden RED, Wheeler BD (1993) Iron toxicity to fen plant species. J Ecol 81:35-46. doi:10.2307/2261222

Stępniewski W, Stępniewska Z, Bennicelli RP, Gliński J (2005) Oxygenology in outline. Institute of Agrophysics, Polish Academy of Science, Lublin

Tockner T, Stanford JA (2002) Riverine flood plains: present state and future trends. Environ Conserv 29:308-330. doi: 10.1017/S037689290200022X

Turner BL, Haygarth BL (2001) Phosphorus solubilisation in rewetted soils. Nature 411:258. doi:10.1038/35077146

Ulbrich U, Brücher T, Fink AH, Leckebusch GC, Krüger A, Pinto JG (2003) The central European floods of August 2002: part 1-rainfall periods and flood development. Weather 58:371-377. doi:10.1256/wea.61.03A

Van den Berg LJL, Dorland E, Vergeer P, Hart MAC, Bobbink R, Roelofs JGM (2005) Decline of acid-sensitive plant species in heathland can be attributed to ammonium toxicity in combination with low $\mathrm{pH}$. New Phytol 166(2):355-704. doi:10.1111/j.1469-8137.2005.01338.x

Van Stokkom HTC, Smits AJM, Leuven RSEW (2005) Flood defence in The Netherlands: a new era, a new approach. Water Int 30:76-87. doi:10.1080/02508060508691839

Zak D, Gelbrecht J, Steinberg CEW (2004) Phosphorus retention at the redox interface of peatlands adjacent to 
surface waters in northeast Germany. Biogeochemistry 70:357-368. doi:10.1007/s10533-003-0895-7

Zak D, Kleeberg A, Hupfer M (2006) Sulphate-mediated phosphorous mobilization in riverine sediments at increasing sulphate concentration, River Spree, NE Germany. Biogeochemistry 80:109-119. doi:10.1007/s10533-0060003-x 